\title{
Surgical management of primary malignant proximal fibular tumors: Functional and clinical outcomes of 23 patients
}

\author{
Primer malign proksimal fibula tümörlerinin cerrahi tedavisi: \\ 23 hastanın fonksiyonel ve klinik sonuçları
}

\author{
İsmail Burak Atalay, $\mathrm{MD}^{1}{ }^{10}$, Selçuk Yılmaz, $\mathrm{MD}^{1}{ }^{\mathbb{D}}$, İzzet Korkmaz, $\mathrm{MD}^{2} \mathbb{D}$, \\ Mehmet Fatih Ekşioğlu, MD'1D, Bedii Şafak Güngör, $M^{1}{ }^{1}$ \\ 'Department of Orthopedics and Traumatology, University of Health Sciences, \\ Dr. Abdurrahman Yurtaslan Ankara Oncology Training and Research Hospital, Ankara, Turkey \\ 2Department of Orthopedics and Traumatology, University of Health Sciences, Atatürk Training and Research Hospital, Ankara, Turkey
}

\begin{abstract}
Objectives: This study aims to evaluate the clinical characteristics and treatment outcomes of patients with primary malignant tumors located in the proximal fibula.

Patients and methods: This retrospective study included 23 patients (15 males, 8 females; mean age 22.1 years; range, 9 to 63 years) with primary malignant tumors located in the proximal fibula between May 2007 and May 2017. The anamnesis or medical history, physical examination, plain chest radiography, lung computed tomography, direct radiograph, and magnetic resonance imaging of the affected extremity and routine laboratory tests of all patients were evaluated.

Results: Of the patients, 11 were diagnosed with osteosarcoma (47.8\%), nine with Ewing's sarcoma (39.1\%), two with chondrosarcoma $(8.7 \%)$, and one was diagnosed with synovial sarcoma (4.3\%). Pain and palpable mass were the most common symptoms. Six patients had lung metastases at the time of diagnosis. Of the patients, eight were performed Malawer type 1 resection (34.8\%), nine type 2 resection (39.1\%), four above knee amputation (17.4\%), and two proximal tibia tumor resection prosthesis (8.6\%). Mean follow-up duration was 36 months (range, 12 to 119 months). Local recurrence developed in three patients. Mean Musculoskeletal Tumor Society (MSTS) score of all patients was 62 .

Conclusion: Surgical treatment of primary malignant tumors of the proximal fibula is problematic. In appropriate indications, Malawer type 1 resection should be the treatment of choice due to lower local recurrence rates and higher MSTS scores.

Keywords: Bone tumor, proximal fibula, tumor resection.
\end{abstract}

\section{$\ddot{O} Z$}

Amaç: $\mathrm{Bu}$ çalışmada proksimal fibula yerleşimli primer malign tümörlü hastaların klinik özellikleri ve tedavi sonuçları değerlendirildi.

Hastalar ve yöntemler: Bu retrospektif çalışmaya Mayıs 2007 ve Mayıs 2017 tarihleri arasında proksimal fibula yerleşimli primer malign tümörü olan 23 hasta (15 erkek, 8 kadın; ort. yaş 22.1 yıl; dağılım, 9-63 yıl) dahil edildi. Tüm hastaların anamnez veya tıbbi öyküsü, fiziksel muayenesi, düz göğüs grafisi, akciğer bilgisayarlı tomografisi, etkilenen ekstremitesinin direkt grafisi ve manyetik rezonans görüntülemesi ve rutin laboratuvar testleri değerlendirildi.

Bulgular: Hastaların 11'ine osteosarkom (\%47.8), dokuzuna Ewing sarkomu (\%39.1), ikisine kondrosarkom (\%8.7) ve birine (\%4.3) sinovyal sarkom tanısı konuldu. Ağrı ve palpabl kitle en sık görülen semptomlardı. Tanı anında altı hastada akciğer metastazı vardı. Hastaların sekizine Malawer tip 1 rezeksiyon (\%34.8), dokuzuna tip 2 rezeksiyon (\%39.1), dördüne diz üstü amputasyon (\%17.4) ve ikisine proksimal tibia tümör rezeksiyon protezi (\%8.6) uygulandı. Ortalama takip süresi 36 ay (dağılım, 12-119 ay) idi. Üç hastada lokal nüks gelişti. Tüm hastaların ortalama Musküloskeletal Tümör Cemiyeti (MSTC) skoru 62 idi.

Sonuç: Proksimal fibulanın primer malign tümörlerinin cerrahi tedavisi problemlidir. Uygun endikasyonlarda, Malawer tip 1 rezeksiyon daha düşük lokal nüks oranları ve daha yüksek MSTC skorları nedeniyle tercih edilen tedavi olmalıdır.

Anahtar sözcükler: Kemik tümörü, proksimal fibula, tümör rezeksiyonu.

Received: September 20, 2018 Accepted: November 27, 2018

Correspondence: İsmail Burak Atalay, MD. SBÜ Dr. Abdurrahman Yurtaslan Ankara Onkoloji Eğitim ve Araștırma Hastanesi Ortopedi ve Travmatoloji Kliniği, 06200, Demetevler, Ankara, Turkey.

Tel: +90 312-3360909 e-mail: drburakatalay@gmail.com 
Only $2.5 \%$ of all benign and malign primary bone tumors are located in the fibula and those requiring extensive resection are usually found in the proximal part. ${ }^{[1]}$ The proximity of the proximal fibula to the popliteal artery and common peroneal nerve division make surgical management of tumors located in this region difficult. ${ }^{[2]}$ The most common malignant primary bone tumors with proximal fibular localization are osteosarcoma and Ewing's sarcoma. ${ }^{[3]}$ Treatment options are neoadjuvant-adjuvant chemotherapy with en-bloc resections of the proximal fibula, proximal tibia resection prosthesis, and extremity amputation. In 1984, Malawer ${ }^{[4]}$ described two different types of resection for benign, aggressive, and malignant tumors of the proximal fibula. Type 1 resection is performed preserving the proximal fibula peroneal nerve whereas in type 2 , wide resection includes proximal part of the fibula, the anterior and lateral muscle compartments, the anterior tibial artery, the peroneal nerve, and the proximal tibiofibular joint. Sacrifice of proximal tibiofibular joint and lateral stabilizators of knee may cause various degrees of knee instability. ${ }^{[3]}$

In this anatomical site, the close proximity of the common peroneal nerve and the anterior tibial artery may be problematic. These structures can be sacrificed to achieve negative surgical margins. Local recurrence is a concern after insufficient surgery due to proximity to critical anatomic structures in primary malignant tumors of the proximal fibula. ${ }^{[1]}$ In this study, we aimed to evaluate the clinical characteristics and treatment outcomes of patients with primary malignant tumors located in the proximal fibula.

\section{PATIENTS AND METHODS}

A retrospective evaluation was performed of 23 patients ( 15 males, 8 females; mean age 22.1 years; range, 9 to 63 years) treated in Orthopedic Oncology Clinic of Ankara Oncology Training and Research Hospital between May 2007 and May 2017 for a diagnosis of malignant primary bone tumor in the proximal fibula. The anamnesis or medical history, physical examination, plain chest radiography, lung computed tomography, direct radiographs, and magnetic resonance imaging (MRI) of the affected extremity and routine laboratory tests of all patients were examined. Incisional biopsy was performed and all patients were evaluated in terms of age at diagnosis, symptoms and findings, tumor size, type of surgical procedure, recurrence, microsurgery limit, chemotherapy, radiotherapy, functional outcomes, and treatment failures. The demographic data and treatment outcomes of patients were tabulated and summarized in Table I. The study protocol was approved by the Ankara Oncology Training and Research Hospital Ethics Committee. A written informed consent was obtained from each patient. The study was conducted in accordance with the principles of the Declaration of Helsinki.

En-bloc resections of the proximal fibula, extremity amputation, and proximal tibia resection prosthesis were performed for the surgical treatment. Malawer type 1 and 2 resections were applied in eight $(34.8 \%)$ and nine $(39.1 \%)$ patients, respectively (Figures 1 and 2). The type of excision was decided according to tumor size, grade, and proximity to major neurovascular structures. ${ }^{[2]}$ Abovekneeamputation was performed in four patients $(17.4 \%)$, while tibia proximal tumor resection prosthesis was performed in two patients $(8.6 \%)$ (Figure 3). All tumors were resected with negative surgical limits. All patients were consulted by the medical and radiation oncologist. No patient received adjuvant or neoadjuvant radiotherapy. All patients with Ewing's sarcoma received neoadjuvant and adjuvant chemotherapy. Nine of 11 patients with osteosarcoma received neoadjuvant chemotherapy and all of them underwent adjuvant chemotherapy. All patients were evaluated according to the Musculoskeletal Tumor Society (MSTS) scoring obtained at their last visit.

\section{RESULTS}

The mean postoperative follow-up period was 36 months (range, 12 to 119 months). Osteosarcoma was diagnosed in 11 patients (47.8\%), Ewing's sarcoma in nine patients (39.1\%), chondrosarcoma in two patients $(8.7 \%)$, and synovial sarcoma in one patient $(4.3 \%)$. Six patients had lung metastases at the time of diagnosis.

Eight patients $(34.8 \%)$ were treated with Malawer type 1 resection with no neurovascular involvement, of which mean tumor size was $5.75 \mathrm{~cm}$. Nine patients $(39.1 \%)$ with neurovascular involvement were treated with type 2 resection, of which mean tumor size was $7.7 \mathrm{~cm}$. Above knee amputation was performed in four patients due to multiple compartment spread of the tumor or involvement of the tibial posterior artery, of which mean tumor size was $12.75 \mathrm{~cm}$. The mean tumor size of all patients was $8.1 \mathrm{~cm}$ (range, 4 to $22 \mathrm{~cm}$ ). The mean MSTS scores of patients were $78.50 \%$ in type 1 resection, $58.5 \%$ in type 2 resection, $45.25 \%$ in knee amputation, and $47 \%$ in tumor resection prosthesis. The mean MSTS score of all patients was $62 \%$. 


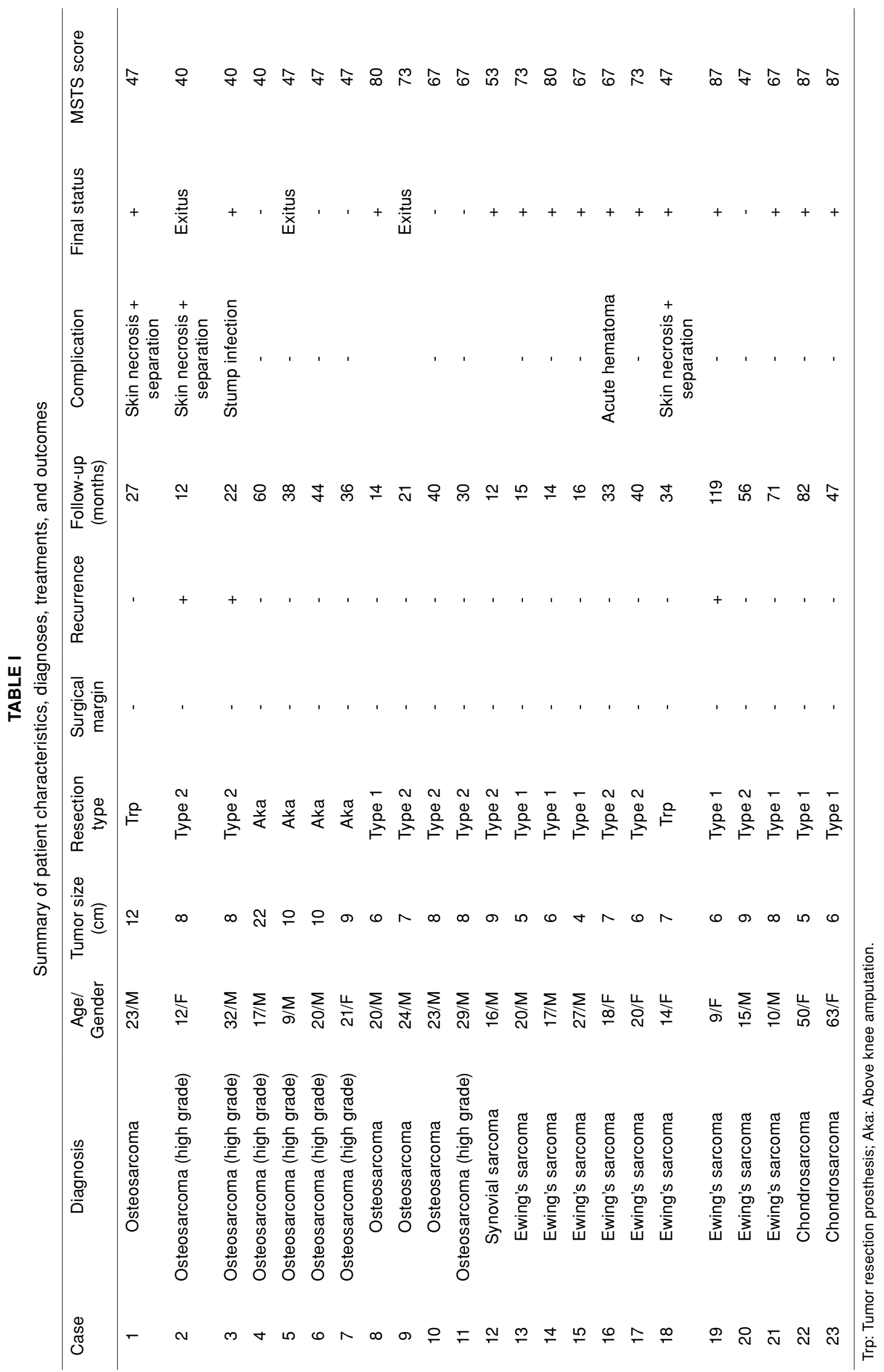



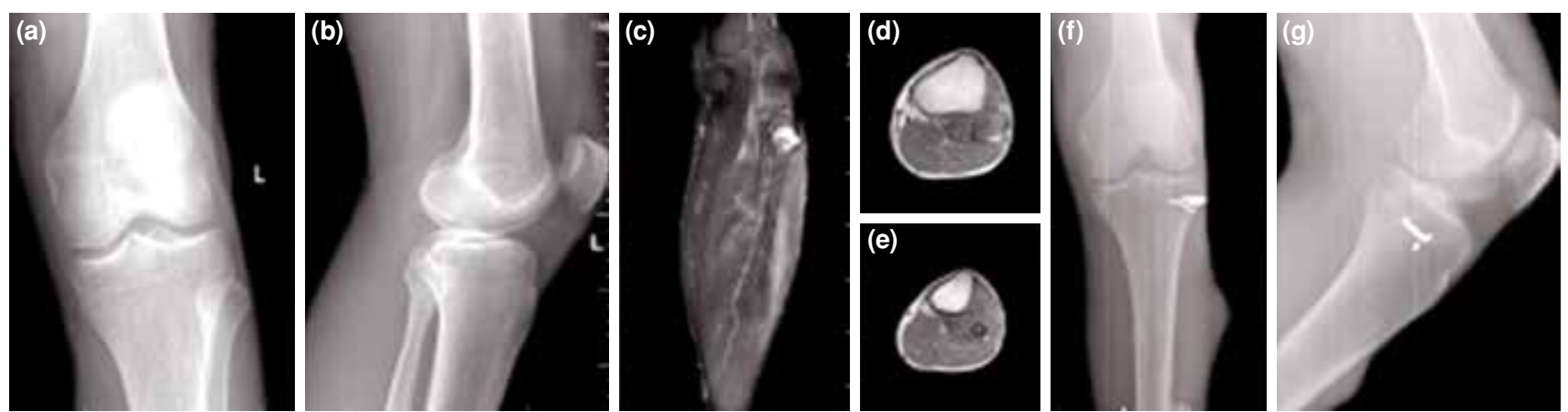

Figure 1. A 27-year-old patient with Ewing's sarcoma of proximal fibula. (a, b) There are no significant preoperative X-ray findings. (c-e) Preoperative magnetic resonance imaging findings show cortical destruction of proximal fibula and soft tissue mass with intensive contrast matter involvement at proximal of lesion. $(\mathbf{f}, \mathbf{g})$ Postoperative X-ray findings of Malawer type 1 resection of fibula and an anchor in proximal tibia for reconstruction of lateral ligament complex (Case no 15).
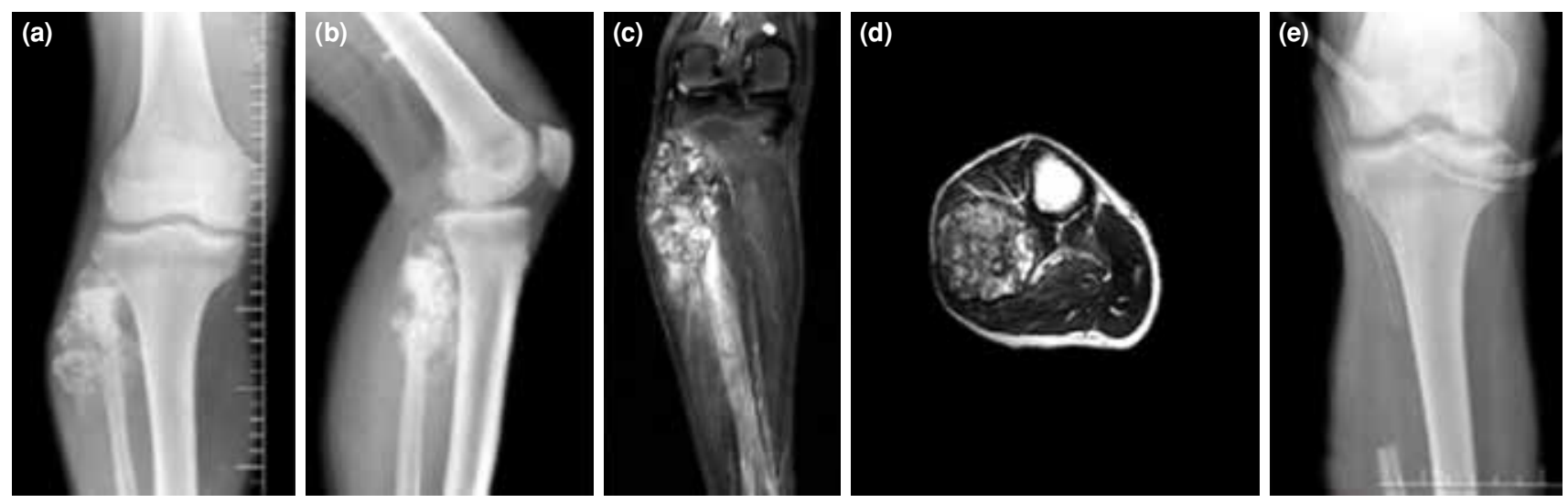

Figure 2. A 29-year-old patient with high-grade osteosarcoma of proximal fibula. (a, b) Preoperative X-ray findings show cortical destruction of proximal fibula. (c, d) Preoperative magnetic resonance imaging findings show invasion of anterior tibial artery, peroneal nerve, and soft tissue mass around fibula. (e) Postoperative X-ray findings show Malawer type 2 resection surgery (Case no 11).
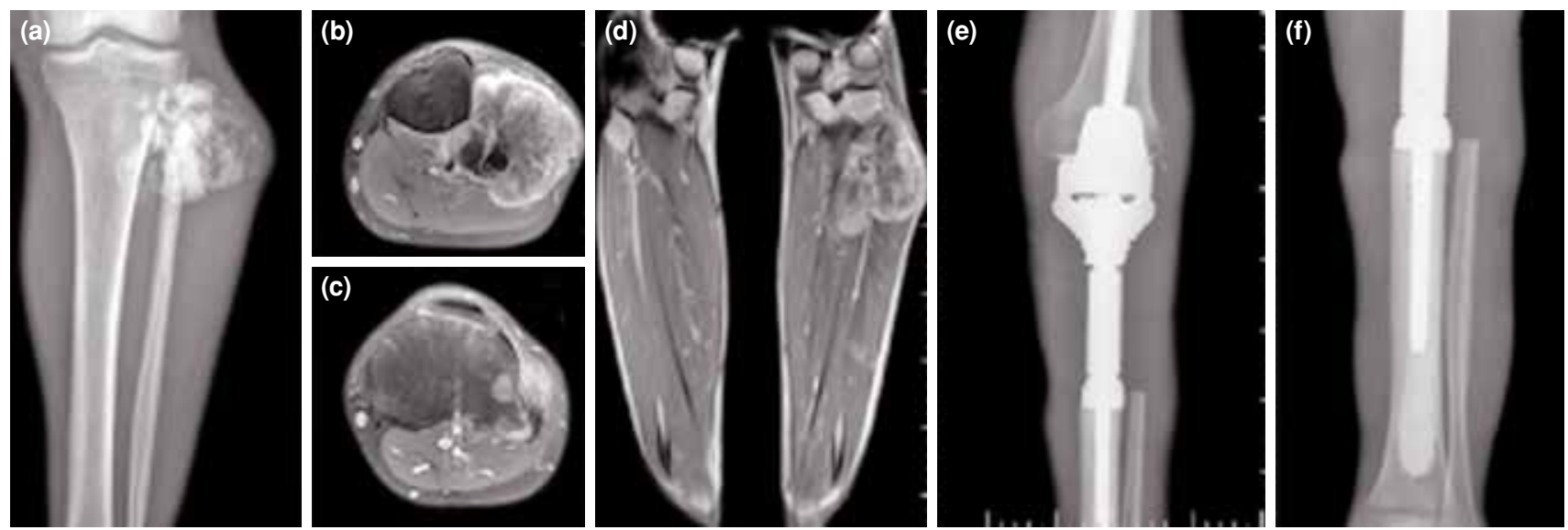

Figure 3. A 23-year-old patient with osteosarcoma of proximal fibula. (a) Preoperative X-ray findings show cortical destruction of proximal fibula. (b, c, d) Preoperative magnetic resonance imaging findings show cortical expansion, destruction of proximal fibula, and skip lesion of tibial lateral plateau. (e, f) Postoperative X-ray findings show tumor resection surgery of proximal tibia (Case no 1).

Intraoperative knee stabilization examination was performed and if valgus instability was detected, the lateral collateral ligament and the lateral head of biceps femoris were re-attached to the lateral wall of the tibia with non-absorbable sutures (ETHIBOND, Ethicon, Somerville, NJ, USA) or bone staple. On follow-up, no patient complained of knee instability and no valgus instability was detected in any patients. 
Local recurrence developed in three patients. Two patients with osteosarcoma were treated with above knee amputation. One patient with Ewing's sarcoma underwent tumor resection.

Wound separation were observed in four patients, two with Malawer type 2 resection and two with proximal tibia resection prosthesis. Debridement and skin closure were performed.

\section{DISCUSSION}

In the current study, a retrospective evaluation was performed of the treatment outcomes of 23 patients with malignant primary bone tumors located in the proximal fibula which were treated with en-bloc resections of the proximal fibula, extremity amputation, and proximal tibia resection prosthesis.

Malawer described two types of fibula resection. Peroneal nerve is preserved in type 1 resection. Whereas in type 2 resection the anterior and lateral muscle compartments, the peroneal nerve, and the anterior tibial arter are completely sacrificied. Schematic illustration of Malawer type 1 and 2 resections are shown in Figure 4 and 5. Contrastenhanced MRI imaging is the basic step in evaluating tumor resectability and deciding on the procedure to be performed. ${ }^{[5]}$ It is useful for calculating tumor volume and determining the relationship between major neurovascular structures. In the current study,

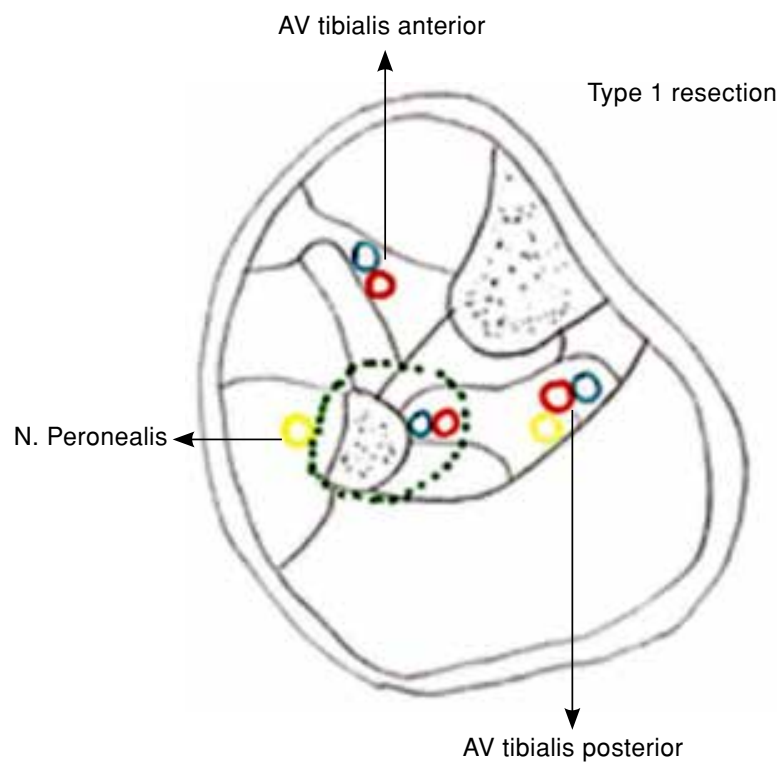

Figure 4. Schematic illustration of Malawer type 1 resection: Resection includes proximal fibula with normal diaphysis and a thin muscle layer while preserving the peroneal nerve. AV: Artery-vein; N: Nerve. all patients were examined with contrast-enhanced MRI preoperatively.

To our knowledge there is no available data about the proximal fibular malignant bone tumor sizes and tumor resection types in the literature. Saini et al. ${ }^{[6]}$ reported the average tumor size to be $6.8 \mathrm{~cm}$ in a study of eight cases diagnosed with osteosarcoma. They performed Malawer type 2 resection in all patients and the mean follow-up period was 48 months. One patient died at postoperative $13^{\text {th }}$ month due to lung metastasis. Complications included synovial fistula in one case, and skin necrosis and superficial infection in another case. Furthermore, Takahashi et al. ${ }^{[7]}$ applied marginal excision, wide excision, and intralesional excision in their 13 patients of osteosarcoma localized in proximal fibula. The mean tumor size was $6.5 \mathrm{~cm}$ (range, 3.5 to $10 \mathrm{~cm}$ ) and they reported local recurrence in six patients.

In gross invasion of the tibia, particularly in multiple compartment spread involving the posterior deep compartment, multi-compartment contamination due to previous biopsy or resection, vascular anomalies, and particularly if the tibialis posterior artery is affected by tumors, above knee amputation is recommended. ${ }^{[6]}$ In the current study, above knee amputation was performed in four patients

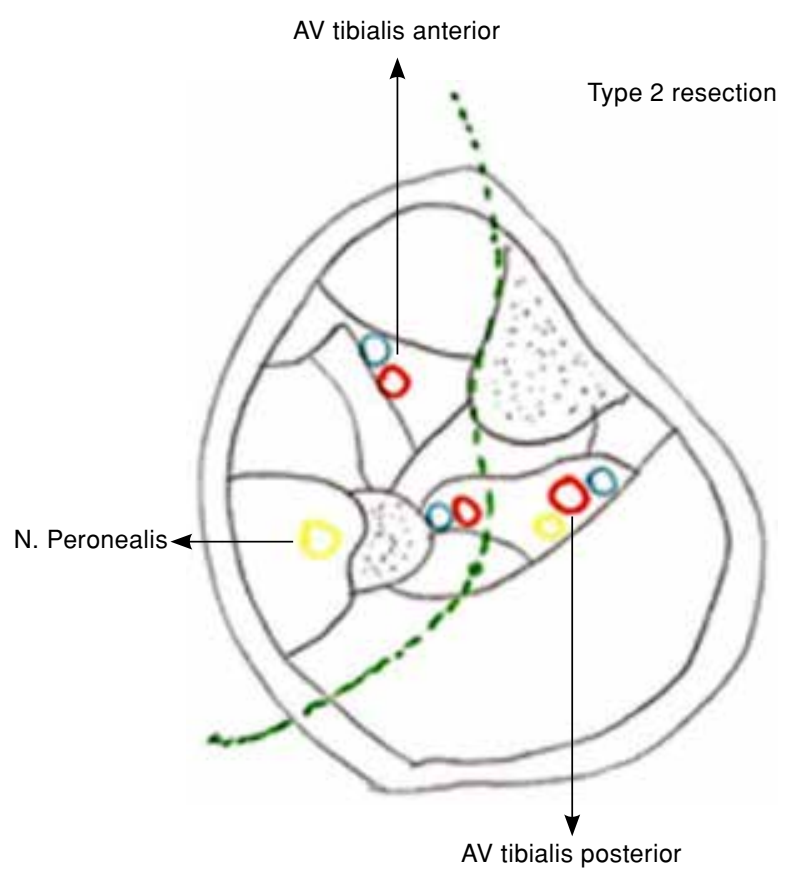

Figure 5. Schematic illustration of Malawer type 2 resection: Resection includes an extra-articular resection of proximal fibula with normal diaphysis, anterior and lateral muscle compartments, anterior tibial artery, peroneal artery, and peroneal nerve. AV: Artery-vein; N: Nerve. 


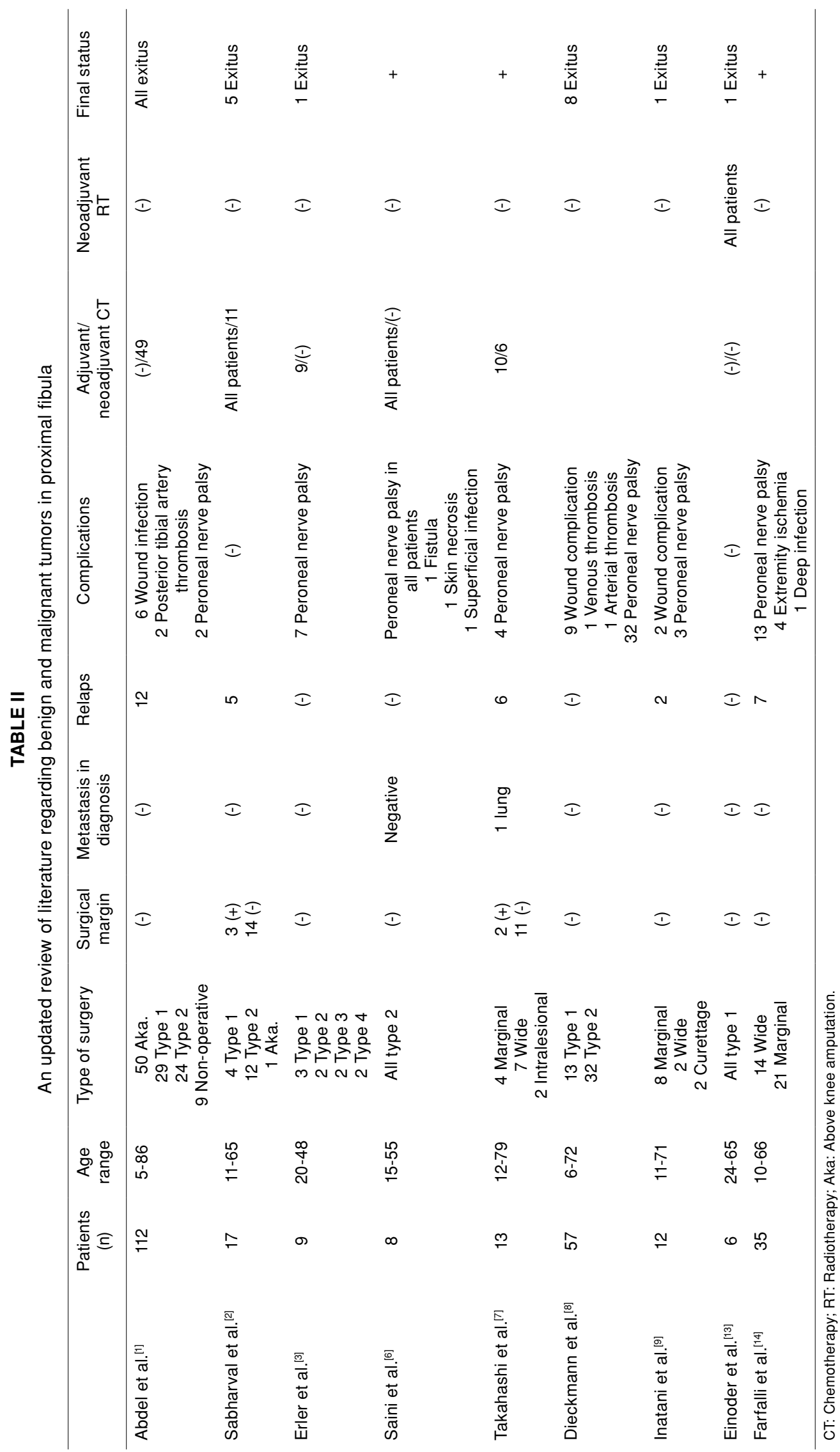


due to multiple compartment spread of the tumor or involvement of the tibial posterior artery.

Proximal tibial resection prosthesis was applied independently from the tumor size in two patients with osteosarcoma and Ewing's sarcoma who had skip metastases in tibia without neurovascular involvement.

To our knowledge, only one study reported MSTS scores of malignant proximal fibular bone tumors treated surgically in the literature; Takahashi et al. ${ }^{[7]}$ applied intralesional excision, wide excision, and marginal excision in 13 osteosarcoma cases and evaluated functional outcomes for eight cases. Their mean functional outcomes were between $87 \%$ and $100 \%$. The MSTS scores of surgically treated benign and malignant proximal fibular tumors are available in the literature. Dieckmann et al. ${ }^{[8]}$ reported the mean MSTS scores as 90 to $97 \%$ for 57 patients with 46 malignant tumors who had undergone fibular resection for benign or malign tumors between 1987 and 2009. Inatani et al. ${ }^{[9]}$ reported 12 patients with benign or malignant tumors who underwent surgery between 1992 and 2011 and indicated the mean MSTS score as $96 \%$ (range, $70 \%$ and $100 \%$ ) for those in whom peroneal nerve could not be resected and as $65 \%$ (range, $60 \%$ and $70 \%$ ) for those in whom the nerve was resected. The mean MSTS score for the whole series in our study was $62 \%$ (range, $40 \%$ and $87 \%$ ). The mean MSTS score of patients who underwent Malawer type 1 resection in which the peroneal nerve was spared $(\mathrm{n}=8)$ was $78.5 \%$ (range, $67 \%$ and $87 \%$ ), while the mean MSTS score was $58.5 \%$ (range, $40 \%$ and $73 \%$ ) for those who underwent type 2 resection in which the peroneal nerve was sacrificed $(n=9)$.

We obtained the best functional outcomes with Malawer type 1 resections. We observed similar outcomes in amputations and proximal tibial tumor resection prosthesis cases. The mean MSTS score is $47 \%$ for those who were applied proximal tibial resection prosthesis and $42.5 \%$ for those who were amputated (range, $40 \%$ and $47 \%$ ). A multidisciplinary approach in a specialized center is required in the management of all localized primary bone tumors. The current treatment of osteosarcoma and Ewing's sarcoma is neoadjuvant chemotherapy, then surgical treatment with local control, followed by chemotherapy. ${ }^{[10]}$ Radiotherapy can be applied for local control or widespread disease. ${ }^{[1]]}$ In cases of chondrosarcoma, chemotherapy and radiotherapy are ineffective and treatment is surgical resection. Chemotherapy can be used before surgery to reduce the size of the tumor. ${ }^{[12]}$ In this study, no patient with chondrosarcoma received chemo-radiotherapy, while all patients with Ewing's sarcoma received neoadjuvant and adjuvant chemotherapy (9 of 11 patients with osteosarcoma received neoadjuvant, while all patients with osteosarcoma received adjuvant chemotherapy). Only a few case series involving proximal tumors of the fibula have been reported in the literature. In a study by Takahashi et al., ${ }^{[7]} 31 \%$ recurrence rate was observed in 13 osteosarcoma cases. Moreover, Sabharval et al. ${ }^{[2]}$ reported $50 \%$ recurrence in eight cases. In the current study, two of 11 cases with osteosarcoma had a recurrence rate of $18 \%$. Abdel et al. ${ }^{[1]}$ evaluated 21 cases diagnosed with Ewing's sarcoma and reported a recurrence rate of $19 \%$. Furthermore, in a study of nine cases by Sabharval et al., ${ }^{[2]}$ the recurrence rate was $11 \%$. In the current study, one recurrence occurred in nine cases (11\%). In 26 cases of chondrosarcoma, Abdel et al. ${ }^{[1]}$ reported a recurrence rate of $7.6 \%$. No recurrence was detected in the two patients with chondrosarcoma in the current study. Moreover, in the current study, local recurrence developed in three patients; two patients with osteosarcoma who underwent Malawer type 2 resection and were treated with above knee amputation and one patient with Ewing's sarcoma treated with tumor resection. Six patients had lung metastases at the time of diagnosis, of whom four had osteosarcoma and two had Ewing's sarcoma. Type 2 resection was carried out for the four osteosarcoma cases with lung metastases. One of the cases died 12 months later and another died 21 months later. Type 1 resection and resection prosthesis were applied for two Ewing's sarcoma cases. After surgery, particularly after type 2 resection, skin necrosis/ delayed wound healing and posterior tibial artery thrombosis may be seen. ${ }^{[1]}$ In the current study, no patient had tibial artery thrombosis. Wound site problems requiring debridement and skin revision were determined in four patients.

Malignant proximal fibular tumors are rarely seen. An updated review of the literature regarding tumors in the proximal fibula is provided in Table II. ${ }^{[1-3,6-9,13,14]}$ Malawer type 1 and type 2 resection is an effective surgical treatment method for tumors diagnosed early, not reaching large sizes, and with no tibial metastasis.

This study has some limitations. It was primarily a retrospective study and the number of cases was limited. Further multicenter studies involving more patients are required.

In conclusion, Malawer type 1 resection should be the treatment of choice in appropriate indications due to lower local recurrence rates and higher MSTS scores. 
The treatment of choice should be amputation for large and widespread tumor masses, approximately $8 \mathrm{~cm}$ or more. Malawer type 1 or type 2 is not suitable for resection in those cases. Proximal tibial resection prosthesis should be performed in patients with metastatic tibia and no major vascular nerve involvement. Intraoperative stability examination should be conducted after tumor resection. Lateral collateral ligament and the lateral head of biceps tendon should be reconstructed if there is valgus instability. Bone staple or non-absorbable sutures may be used as reconstruction material.

\section{Declaration of conflicting interests}

The authors declared no conflicts of interest with respect to the authorship and/or publication of this article.

\section{Funding}

The authors received no financial support for the research and/or authorship of this article.

\section{REFERENCES}

1. Abdel MP, Papagelopoulos PJ, Morrey ME, Inwards CY, Wenger DE, Rose PS, et al. Malignant proximal fibular tumors: surgical management of 112 cases. J Bone Joint Surg [Am] 2012;94:165.

2. Sabharwal S, Datta G, Berber O, Aston W, Pollock R, Briggs T. Malignant proximal fibular tumours: a case series of 17 patients. Acta Orthop Belg 2011;77:795-801.

3. Erler K, Demiralp B, Ozdemir MT, Basbozkurt M. Treatment of proximal fibular tumors with en bloc resection. Knee 2004;11:489-96.

4. Malawer MM. Surgical management of aggressive and malignant tumors of the proximal fibula.
Clin Orthop Relat Res 1984;186:172-81.

5. Beytemür O, Tetikkurt ÜS, Albay C, Adanır O, Güleç MA. Acute myeloid leukemia diagnosed with soft tissue mass in the right thigh. [Article in Turkish] Eklem Hastalik Cerrahisi 2015;26:56-9.

6. Saini R, Bali K, Gill SS, Mootha AK, Dhillon MS. En bloc resection of osteosarcoma of the proximal fibula. An analysis of 8 cases. Acta Orthop Belg 2010;76:806-10.

7. Takahashi S, Ogose A, Tajino T, Osanai T, Okada K. Osteosarcoma of the proximal fibula. An analysis of 13 cases in the northern Japan. Ups J Med Sci 2007;112:366-72.

8. Dieckmann R, Gebert C, Streitbürger A, Henrichs MP, Dirksen U, Rödl R, et al. Proximal fibula resection in the treatment of bone tumours. Int Orthop 2011;35:1689-94.

9. Inatani H, Yamamoto N, Hayashi K, Kimura H, Takeuchi A, Miwa S, et al. Surgical management of proximal fibular tumors: A report of 12 cases. J Bone Oncol 2016;5:163-6.

10. Görgün Ö, Salduz A, Kebudi R, Özger H, Bilgiç B. Malignant transformation of aggressive osteoblastoma to ostesarcoma. Eklem Hastalik Cerrahisi 2016;27:108-12.

11. Siller CS, Lewis IJ. Update and review of the management of bone tumours. Paediatrics and Child Health March 2010;20:103-8.

12. Pattanashetty OB, B B D, Pillai A, Endigeri P. Dedifferentiated Chondrosarcoma of Proximal Tibia and Fibula with an Infected Ulcer: A Case Report. J Orthop Case Rep 2016;6:9-12.

13. Einoder PA, Choong PF. Tumors of the head of the fibula: good function after resection without ligament reconstruction in 6 patients. Acta Orthop Scand 2002;73:663-6.

14. Farfalli GL, Albergo JI, Ayerza MA, Muscolo DL, AponteTinao LA. Surgical treatment of locally aggressive and malignant tumors of the proximal third of the fibula. Oncology results and functional evaluation. Rev Esp Cir Ortop Traumatol 2014;58:212-6. 